\title{
The Automotive Production And Development Programme: An Analysis Of The Opinions Of South African Stakeholders
}

\author{
Evádne Bronkhorst, University of Pretoria, South Africa \\ Jasper Steyn, University of Pretoria, South Africa \\ Madeleine Stiglingh, University of Pretoria, South Africa
}

\begin{abstract}
The development of a specific industry could enhance a country's economic growth by facilitating its global positioning. Some industries may require government support to enable meaningful economic contribution. The South African government provided support to its automotive industry via the Motor Industry Development Programme (MIDP) since 1995. The MIDP ended in 2012, and is being replaced by the Automotive Production and Development Programme (APDP) from 2013. The APDP will extend support to the South African automotive industry until 2020. The motivation for the extension is to continue providing support to South Africa's automotive industry in its attempt to become a sustainable global competitor with reduced reliance on government support. This article analyses the opinions of relevant stakeholders on the anticipated performance of the South African automotive industry under the APDP. It was motivated by the fact that there is currently no research available on the anticipated performance of the South African automotive industry under the APDP. It also highlights the link between stakeholders' opinions and the documented performance of the MIDP as well as the design of the APDP's policy instruments. Data was gathered by using a survey that was distributed to relevant stakeholders in the South African automotive industry. The results show that where there is policy uncertainty, the perceived risk impacts the opinions of relevant stakeholders. Consequently, there is much uncertainty among participating stakeholders regarding the APDP's ability to satisfy policy objectives. The majority of stakeholders agreed that the APDP is a World Trade Organization compliant programme and that it will facilitate increased research and development spend. However, there are reservations about the possible negative impact of the APDP's policy instruments on the South African automotive industry's exports as well as the future of the local automotive components industry. It is therefore recommended that governments should ensure that policy design is transparent and is finalised and communicated early enough to afford relevant stakeholders sufficient time to respond appropriately.
\end{abstract}

Keywords: Automotive Production and Development Programme; Motor Industry Development Programme; Customs Duty; Automotive Industry

\section{INTRODUCTION}

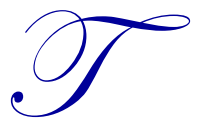

he subsidisation of a specific industry of the economy by government is a controversial issue. The reason why industry subsidisation remains controversial is best summed up in the following question: “...[W]hat opportunities will be lost to us as a result of the decision to opt for the subsidisation of car manufacturing, rather than, say, cheaper education?" ("South Africa", 2008). Still, governments continue to be motivated to award subsidies to specific industries in order to alleviate increased international competitive pressures brought about by globalisation (Barnes \& Kaplinsky, 2000, p. 797; Lamprecht, 2006, pp. 1-4). 
The automotive industry is one of the largest global economic and socio-economic contributors and believed to be essential to the well-being of the global community (OICA, 2007). Being a large industry globally, there are also a number of contenders for global market share contributing to continuing competitive pressures. It is therefore not surprising that a number of governments are focusing their efforts on developing this industry through subsidisation (GCIS, 2008).

The automotive industry is also one of the largest economic contributors in South Africa. It is estimated that the South African automotive industry contributed 6.8\% to the country's gross domestic product in 2011 (NAAMSA, 2012, p. 6). This is the largest contribution by an automotive industry to gross domestic product on the African continent (Johnsons Matthey, 2012, p. 1). Globally, however, South Africa's automotive industry is still relatively small. Despite subsidisation for a number of years, the South African automotive industry only contributed $0.66 \%$ to global vehicle production in 2011 . While national production growth has been commendable, other developing markets such as China and India continue to be formidable global market share contenders (NAAMSA, 2012, p. 6).

The South African automotive industry was isolated for some 15 years from the 1980s until 1994 on account of apartheid-driven sanctions (Barnes, Kaplinsky \& Morris, 2003, p. 3; Black, 2002, p. 2). Apart from the fact that the industry used to be inwardly-orientated, a profusion of other issues, such as poor quality products, outdated products and inefficient supplier chains arose. Over a number of years, local content programmes, introduced under South Africa's industrial policy, were altered to address these issues (Barnes \& Kaplinsky, 2000, pp. 799-801; Flatters, 2005, pp. 8-14; Kaplan, 2003, p. 21). However, these alterations still failed to create economies of scale and to rationalise the number of vehicle models produced locally (Black \& Mitchell, 2002, pp. 16; Black \& Bhanisi, 2007, pp. 135-136).

The disappointing performance of the South African automotive industry resulted in the introduction of the Motor Industry Development programme (MIDP) in September 1995. The MIDP was introduced to assist the South African automotive industry to become globally integrated and increase its competitiveness (DTI, 2003, p. 10). Compared to India and China, the MIDP did not assist the South African automotive industry in becoming a sustainable global market share contender (NAAMSA, 2012, p. 6). A literature review on the performance of the MIDP conducted by Bronkhorst (2010, pp. 31-75), also indicated that the MIDP was not successful in achieving all the policy objectives set by the South African government. Despite the aforementioned, the South African government, through its Department of Trade and Industry (DTI), has decided to continue to support the South African automotive industry (DTI, 2010b, p. 3).

The MIDP ended in 2012 and is being replaced by the Automotive Production and Development Programme (APDP). The APDP, a product of the review of the MIDP, will be implemented in order to assist the industry in facing the demands of a highly competitive global industry. All of the APDP's policy instruments will become fully operational in 2013 and will be in place until 2020 (DTI, 2010b, p. 3). The inherent nature of the APDP differs from that of the MIDP in that it is a local manufacturing incentive and not an export-based incentive (Deloitte and Touche, 2009, p. 1).

The fact that the automotive industry is one of the largest economic contributors in a national sense (NAAMSA, 2012, p. 6), may be one of the reasons for the South African government's decision to continue supporting the South African automotive industry. Another reason may be the possibility that the industry may not survive globally without support by the South African government (GCIS, 2008). This was confirmed by a study conducted by Lamprecht (2006, p. 204) which revealed that industry stakeholders were of the opinion that the South African automotive industry would not be able to compete globally in the absence of the MIDP.

The Organisation for Economic Co-operation and Development (OECD) confirmed in its Global Forum on International Investment of 2001, that investment is a key element in facilitating the global positioning of a country and its industries. Investment, in turn, can be influenced by economic policy (including industrial policies such as the MIDP and the APDP) (OECD, 2001, p. 1). Therefore, policy can be used to influence the behavior of investors in order to attract investment thereby achieving policy objectives (Hall \& Jorgenson, 1967, p. 391). 
South Africa's economy "relies upon investment and domestic consumer demand" (DTI, 2003, p. 32). Investment, production levels and local content are inter-dependent. An increase in investment may result in an increase in production capacity, which may in turn result in an increase in the number of units produced. On the other hand, if state-of-the-art facilities are available for producing vehicles and components of the standard required internationally, there will be a greater incentive to produce locally. By making use of more locally produced components, there will be an increase in the level of local content in vehicles (Black \& Bhanisi, 2007, p. 144; Barnes \& Morris, 2008, pp. 47, 51). Therefore it can be deduced that investments, production volumes and local content are inter-dependent.

The long-term development objectives of the APDP is to increase production volumes to 1.2 million by 2020 and to "deepen" the local components industry (DTI, 2008). The success of the APDP may depend on the perceptions of the stakeholders whose behavior it intends to influence. If there is no perceived benefit, stakeholders might not behave in a manner conducive to achieving policy objectives. While policies cannot foresee stakeholders' actions in response to the incentive on offer, it may be useful to obtain the opinions of stakeholders as this can provide an indication of whether or not the policy objectives can be achieved (Dolan, Hallsworth, Halpern, King \& Vlaev, 2010, pp. 7-10; Policy Studies Institute, 2006, pp. 15-17). Empirical research undertaken by Black in 1995, before the implementation of the MIDP, indicated that stakeholders that were aware of impending policy changes were surprisingly accurate in forecasting the impact of the implementation of a new automotive programme (Black, 2001, p. 8).

While research has been conducted to evaluate the performance of the MIDP (Barnes, et al., 2003; Black \& Bhanisi, 2007; Black, 2001; Black, 2002; Flatters, 2005; Flatters \& Netshitomboni, 2006; Lamprecht, 2006), only limited information could be found regarding whether the APDP will continue to support the South African automotive industry in becoming internationally competitive. The aim of this article is to analyse the opinions of relevant stakeholders regarding the anticipated performance of the APDP, as this could provide an indication of the achievability of the APDP's policy objectives.

\section{RESEARCH DESIGN AND DATA ANALYSES}

The MIDP was used as a basis for the design of the APDP. As the MIDP has been in operation since 1995, stakeholders have experience in its application. Stakeholders can therefore readily draw from their experiences regarding the MIDP in evaluating the APDP. The opinions of stakeholders regarding the MIDP effectively create a frame of reference from which they can draw in forming their opinions on the APDP. Therefore, it was necessary to first obtain the opinions of stakeholders regarding the MIDP.

In Bronkhorst (2010, pp. 10-75 \& 106-109) a literature review was performed to identify the policy objectives of the MIDP and the APDP. A comparison of these objectives revealed that the objectives of the APDP are based on the objectives of the MIDP (Bronkhorst, 2010, pp. 106-109). The similarities between the objectives of these policies made it possible to use the MIDP's objectives to design a set of common critical success factors (CSFs) (refer Table 1). The CSFs were developed by the performance of a literature review on both the policy objectives of the MIDP, as formulated by the DTI, and the documented performance of the MIDP (Bronkhorst, 2010, pp. 10-75). These CSFs were then used to formulate survey questions for inclusion in the chosen data collection instrument, a self-administered web-based survey. The same set of survey questions were used in relation to both the MIDP and the APDP. By forming opinions on the MIDP first, stakeholders were given the opportunity to assess how their opinions would change regarding the anticipated performance of the APDP, given the change in policy instruments included in the APDP.

The use of the same CSFs to collect opinions regarding both the MIDP and the APDP established a common benchmark which facilitated comparability. Stakeholders were required to indicate whether they agree or disagree on whether the MIDP has achieved a certain CSF and whether the APDP will achieve a certain CSF (refer Table 1). The survey response categories were grouped as follows for purposes of statistical analysis:

- "Strongly Agree" and "Agree": Grouped together under "Agree";

- "Strongly Disagree" and "Disagree": Grouped together under "Disagree"; and

- "Uncertain" 
Table 1: Critical Success Factors

\begin{tabular}{|c|c|c|}
\hline \multirow{13}{*}{ 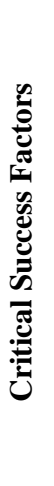 } & The MIDP has Created & The APDP will Create \\
\hline & \multicolumn{2}{|c|}{ Affordable motor vehicles } \\
\hline & \multicolumn{2}{|c|}{ Affordable components } \\
\hline & \multicolumn{2}{|c|}{ Increased exports } \\
\hline & \multicolumn{2}{|c|}{ Decreased imports } \\
\hline & \multicolumn{2}{|c|}{ An improved automotive industry trade balance } \\
\hline & \multicolumn{2}{|c|}{ Sustainable exports } \\
\hline & \multicolumn{2}{|c|}{ Diversified component exports } \\
\hline & \multicolumn{2}{|c|}{ An increase in the local content of motor vehicles } \\
\hline & \multicolumn{2}{|c|}{ An increase in the local content of components } \\
\hline & \multicolumn{2}{|c|}{ Rationalisation of the number of vehicle models produced locally } \\
\hline & \multicolumn{2}{|c|}{ An increase in local research and development activities } \\
\hline & \multicolumn{2}{|c|}{ Compliance with the requirements of the World Trade Organization } \\
\hline
\end{tabular}

The study is of an explorative nature and a web-based survey was judged to be able to provide sufficient information to execute an analysis of stakeholders' opinions. Furthermore, it was important that the results were representative of South Africa. As stakeholders were dispersed throughout South Africa, this instrument enabled contact with stakeholders across the entire country at a relatively low cost.

The population of this study was comprised of stakeholders with a manufacturing investment decisionmaking stake in the automotive industry. As previously stated, the opinions of stakeholders with a stake in investment decisions in the South African automotive industry are relevant, as their opinions could indicate whether or not investment will be increased that could impact the extent to which policy objectives will be achieved (Dolan et al., 2010, pp. 7-10; Hall \& Jorgenson, 1967, p. 1; Policy Studies Institute, 2006, pp. 15-17).

The population of this study comprises a fair representation of the automotive industry. Members of the National Association of Automobile Manufacturers of South Africa (NAAMSA) and National Automotive Component and Allied Manufacturers (NAACAM) as at March 2010, involved in the light motor vehicle industry, were considered to be stakeholders for this study. One expert consultant that regularly supported the South African government on the MIDP's design, was also included in the population. "The eight original equipment manufacturers (OEMs), as the key drivers of the automotive supply chain, and the key industry stakeholders, representing the supporting subsectors of the automotive supply chain, represent the domestic automotive supply chain" (Lamprecht, 2009, p. 11). Both the OEMs manufacturing light vehicles in South Africa and the key industry stakeholders referred to by Lamprecht (2009, p. 11) were also included within the target population of this study, as they are included in the NAAMSA and NAACAM member lists.

The NAAMSA and NAACAM membership lists also include stakeholders that do not have a manufacturing investment decision-making stake in the manufacturing of light motor vehicles. The methods available to identify these stakeholders would be to review each one's website or inspect the member activity descriptions in the membership list. In certain instances it was possible to determine with certainty those stakeholders to be excluded from the population. However, there was the occasional risk that the incorrect interpretation of information could result in the omission of stakeholders who could make a valuable contribution to the study. As a result of this uncertainty, these stakeholders were included in the population. As a result of not being able to accurately determine the target population, it was expected that this would impact the response rate. Reliance was placed on the performance of a self-evaluation by respondents in terms of the applicability of the survey and their ability to form and communicate their opinions.

The survey was distributed to 200 stakeholders in the form of a hyper-text-mark-up-link contained in an electronic mail. Two follow-up participation requests were distributed to facilitate an increase in the response rate. 58 of the stakeholders participated in the study, 36 of whom completed all the questions needed for statistical analyses. This represents a response rate of $18 \%$. Response rates for studies in the taxation arena have delivered similar response rates (i.e. 5\% and 14.5\%) (Smulders \& Stiglingh, 2008, p. 357; Stiglingh, 2008, p. 103). A similar study on the South African automotive industry yielded a response rate of $100 \%$. However, the population for this study was much smaller (i.e. 23 respondents) (Lamprecht, 2009, p. 367). The study was also not a classic 
quantitative study. The aim was to obtain the opinions of stakeholders that are subject matter experts rather than to achieve a high response rate. The web-based survey also provided stakeholders with the opportunity to perform a self-assessment of their desire and ability to express an opinion (i.e. whether or not they are subject matter experts).

The Bowker's Test was utilised to compare the perceived performance of the MIDP with the anticipated performance of the APDP. The Bowker's Test is essentially the same as McNemar's Test, the aim of which is to determine, for each hypothesis formulated, whether or not "...the proportions of subjects with the characteristic of interest is the same under two conditions/treatments" (Diamantopoulos \& Schlegelmilch, 2000, p. 192). The aim of Bowker's Test is very similar, except that more than two conditions/treatments are present (SAS Institute Inc., 2010, p. 154). Under the Bowker's Test, $p$-values are determined which provides an indicator of change. Where the $p$ value is less than 0.05 , it indicated that there was a significant change in the opinions of stakeholders regarding the change in policy design (from the MIDP to the APDP) (PQSTAT, 2012).

As the analysis of the research results requires an understanding of the policy instruments included in both the MIDP and the APDP, the next section will provide a brief overview of these instruments.

\section{POLICY INSTRUMENTS OF THE MIDP AND THE APDP}

The MIDP and the APDP are selective policies as they focus on the promotion of a specific industry - the automotive industry (Barnes et al., 2003, p. 5). The benefits granted to the automotive industry via the policy instruments contained in the MIDP mainly consisted of the forgoing of import tariff revenues by the South African government. Under the APDP, financial contributions will be made by the South African government in the form of cash grants, in addition to the forgoing of import tariff revenues. Therefore these policy instruments are classifiable as subsidies in accordance with article 1 subsection 1.1 (a)(1) of the Agreement on Subsidies and Countervailing Measures ("Agreement"). The Agreement is applicable to South Africa as it is a World Trade Organization (WTO) member (WTO, 2008, p. 229).

Four different policy instruments were included in the MIDP, the first being the duty/tariff phase down instrument. Import duties on the importation of completely built-up (CBU) light motor vehicles decreased from 38\% since 1 January 2003 to $25 \%$ on 1 January 2012. Import duties on the importation of components used in an assembly process was reduced from $29 \%$ to $20 \%$ (for the same period). The phase-down rates of the duties (1\% per annum from 1 January 2007 onwards) was greater than what was required by the WTO (Black, 2002, p. 6; DTI, 2003, p. 11). The second policy instrument was the Duty Free Allowance (DFA) which encouraged the production of vehicles for the domestic market by awarding an allowance of $27 \%$ that could first be utilised to reduce the customs duty value of components to be used in the production of motor vehicles for the South African Customs Union Market, and subsequently to reduce the customs duty value of motor vehicles (SARS, 2009, pp. 59-61). The third policy instrument which was included is the Productive Asset Allowance (PAA), an investment incentive structured to assist the automotive industry to adapt to global demands. It comprised a duty rebate of $20 \%$ of the capital investment in productive assets. Its main objective was to support investment in globally competitive manufacturing equipment. In order to qualify, OEMs had to rationalise vehicle platforms to enable an increase in local production volumes, particularly of components, thereby enhancing economies of scale and cost competitiveness for sustainability. The allowance was distributed over 5 years (i.e. $4 \%$ per year) and could be applied only by OEMs that manufactured light vehicles in South Africa, to reduce the import duty on light motor vehicles (Kaggwa, Pouris \& Steyn, 2007, p. 684). The last policy instrument of the MIDP was the Import-Export Complementation (IEC) scheme. This instrument was included to facilitate an expansion in domestic production by encouraging manufacturers to venture into export markets. Import rebate credit certificates (IRCCs) were awarded for the local content of exports and could be used to reduce the import tariff liability (Black \& Mitchell, 2002, p. 13; SARS, 2004, pp. 18-19).

The APDP also incorporates four policy instruments. The first policy instrument included in the APDP is stabilised import tariffs. The duty / tariff phase down under the MIDP ceased in 2012. From 2013 onwards the tariffs will remain stable under the APDP, at $25 \%$ on CBU light motor vehicles and 20\% on components (SAABC, 2008a, p. 2). The second policy instrument is the Automotive Investment Scheme (AIS), a taxable cash grant of up to 30\% of capital investment in productive assets that is awarded to eligible applicants for qualifying projects, provided that 
certain mandatory requirements are complied with (DTI, 2010a, pp. 7-9). The Automotive Investment Scheme Programme Guidelines, published by the DTI during May 2010, provide details regarding the functioning of this instrument (DTI, 2010a, pp. 1-28). The third policy instrument is the Production Incentive (PI), an import duty rebate credit based on the amount of local value added (therefore a production-based incentive instrument). The fourth policy instrument is the Volume Assembly Allowance (VAA) that allow assemblers producing more than 50 000 vehicles annually, for any market, to import a percentage of their components for building these vehicles duty free (SAABC, 2008a, p. 3).

\section{RESEARCH RESULTS ANALYSES}

This article focuses only on those CSFs where stakeholders' opinions regarding the anticipated performance of the APDP, were significantly different from their opinions regarding the performance of the MIDP (i.e. where the APDP's performance is expected to differ significantly from that of the MIDP). The level of support or the cost thereof to the South African government and any other automotive programmes (other than the MIDP and the APDP) are not within the scope of this article.

The purpose of the survey was to capture the opinions of stakeholders regarding the performance of the MIDP and anticipated performance of the APDP with reference to the formulated CSFs.

The majority of participating manufacturing stakeholders (64\%) were registered under the MIDP and were of the opinion that they would be eligible to register under the APDP (58\%). It is therefore concluded that the respondents were equipped to provide authoritative answers to the survey. However, it is submitted that the registration status of stakeholders would not necessarily preclude participation as the role of the stakeholders may require knowledge of relevant automotive programmes. 78\% of all respondents had estimated sales of R100 million or greater per annum, while $25 \%$ had estimated sales of R1 billion or greater per annum. Of the participating stakeholders, $78 \%$ were involved in exporting to some extent, and of the $75 \%$ of participating stakeholders forming part of a group, $63 \%$ were foreign-owned. $89 \%$ of the respondents had 100 or more employees with $22 \%$ employing 1000 and more employees. Therefore the respondents were sufficiently equipped to formulate opinions on both economic and socio-economic aspects of the policies.

At the date of writing this article, the details of the APDP have still not been finalised (Pitot, 2012). This uncertainty introduces an element of risk into planning by stakeholders.

The impact of policy uncertainty on behaviour and decision-making has been a topic of interest for many researchers. At the crux of most of the research conducted is the observation that uncertainty will change behaviour but that econometric assessment of the extent thereof may be difficult to measure. This is because there are many inter-dependencies that influence decision-making, even more so as a result of globalisation where the impact of international forces also requires consideration (Alm, 1988; Bizer \& Judd, 1989; Edmiston, Mudd and Valev, 2003; Rodrik, 1991).

The success of the APDP could depend on the psychology of expectations. Rational behaviour would most likely call for the deferral of decision making until the level of uncertainty regarding the APDP has been reduced to an acceptable level (Rodrik, 1991).

Therefore stakeholders' opinions could assist in predicting structural changes in the automotive industry mostly where there is policy certainty. While perfect foresight would not be possible, stakeholders' ability to provide conclusive opinions would be adversely impacted by an environment of uncertainty (Alm, 1988; Bizer \& Judd, 1989; Edmiston et al., 2003; Rodrik, 1991). Because of the prevailing uncertainty regarding the details of the APDP and the fact that it has yet to be fully implemented (Pitot, 2012), the interpretation of stakeholders' opinions in conjunction with an analysis of current policy design, could only provide a rough indication of expected structural changes. In an uncertain environment, final conclusions would not be appropriate. It was therefore expected that there would be a greater degree of uncertainty among participating stakeholders where the policy outcome has either not been finalised or where the performance of the specific policy instrument relies mostly on the future actions of certain stakeholders. 
Each of the CSFs for which there was a significant change in the opinions of stakeholders, will now be discussed separately following the ranking outlined in Table 2. The discussion of CSFs three, four and eight was combined due to their strong linkage.

The results in Table 2 were ranked based on the significance of the change in opinions of stakeholders (represented by the $p$-value). In other words, the results appear in ascending order; the smaller the $p$-value the greater the increase in the significance of the change in opinions.

Table 2: Opinions of Stakeholders

\begin{tabular}{|c|c|c|c|c|c|c|c|c|c|}
\hline \multirow{2}{*}{$\begin{array}{l}\text { CSF } \\
\text { No. }\end{array}$} & \multirow{2}{*}{$\begin{array}{c}\text { The MIDP has Created / The } \\
\text { APDP will Create }\end{array}$} & \multicolumn{3}{|c|}{ MIDP\% } & \multicolumn{3}{|c|}{ APDP \% } & \multirow[b]{2}{*}{$P$-value ${ }^{4}$} & \multirow{2}{*}{$\begin{array}{c}\text { Significant } \\
\text { Change in } \\
\text { Opinions }\end{array}$} \\
\hline & & $\mathbf{A}^{1}$ & $\mathrm{D}^{2}$ & $\mathbf{U}^{3}$ & $\mathbf{A}^{1}$ & $\mathrm{D}^{2}$ & $\mathbf{U}^{3}$ & & \\
\hline 1 & $\begin{array}{l}\text { Compliance with the requirements } \\
\text { of the World Trade Organization } \\
\text { (Refer to section 4.1) }\end{array}$ & $14 \%$ & $72 \%$ & $14 \%$ & $67 \%$ & $6 \%$ & $28 \%$ & $<0.0001$ & \multirow{8}{*}{ Yes } \\
\hline 2 & $\begin{array}{c}\text { Sustainable exports } \\
\text { (Refer to section 4.2) }\end{array}$ & $86 \%$ & $8 \%$ & $6 \%$ & $36 \%$ & $28 \%$ & $36 \%$ & 0.0004 & \\
\hline 3 & $\begin{array}{c}\text { Decreased imports } \\
\text { (Refer to section 4.3) }\end{array}$ & $36 \%$ & $58 \%$ & $6 \%$ & $36 \%$ & $25 \%$ & $39 \%$ & 0.0029 & \\
\hline 4 & $\begin{array}{c}\text { Increased exports } \\
(\text { Refer to section } 4.3)\end{array}$ & $89 \%$ & $8 \%$ & $3 \%$ & $47 \%$ & $36 \%$ & $17 \%$ & 0.004 & \\
\hline 5 & $\begin{array}{c}\text { An increase in the local content of } \\
\text { motor vehicles } \\
\text { (Refer to section 4.4) }\end{array}$ & $61 \%$ & $33 \%$ & $6 \%$ & $58 \%$ & $6 \%$ & $36 \%$ & 0.0066 & \\
\hline 6 & $\begin{array}{l}\text { An increase in the local content of } \\
\text { components } \\
\text { (Refer to section 4.5) }\end{array}$ & $64 \%$ & $25 \%$ & $11 \%$ & $64 \%$ & $3 \%$ & $33 \%$ & 0.009 & \\
\hline 7 & $\begin{array}{c}\text { Affordable motor vehicles } \\
\text { (Refer to section 4.6) }\end{array}$ & $50 \%$ & $39 \%$ & $11 \%$ & $44 \%$ & $19 \%$ & $36 \%$ & 0.0117 & \\
\hline 8 & $\begin{array}{c}\text { An improved automotive industry } \\
\text { trade balance } \\
\text { (Refer to section } 4.3 \text { ) }\end{array}$ & $64 \%$ & $28 \%$ & $8 \%$ & $47 \%$ & $17 \%$ & $36 \%$ & 0.0147 & \\
\hline 9 & $\begin{array}{c}\text { An increase in local research and } \\
\text { development activities } \\
\text { (Refer to section 4.7) }\end{array}$ & $25 \%$ & $53 \%$ & $22 \%$ & $39 \%$ & $22 \%$ & $39 \%$ & 0.02 & \multirow{4}{*}{ Yes } \\
\hline 10 & $\begin{array}{l}\text { Diversified component exports } \\
\text { (Refer to section 4.8) }\end{array}$ & $56 \%$ & $30 \%$ & $14 \%$ & $31 \%$ & $33 \%$ & $36 \%$ & 0.0223 & \\
\hline 11 & $\begin{array}{c}\text { Affordable components } \\
\text { (Refer to section 4.9) }\end{array}$ & $56 \%$ & $30 \%$ & $14 \%$ & $42 \%$ & $25 \%$ & $33 \%$ & 0.046 & \\
\hline 12 & $\begin{array}{l}\text { Rationalisation of the number of } \\
\text { vehicle models produced locally } \\
\text { (Refer to section 4.10) }\end{array}$ & $78 \%$ & $17 \%$ & $5 \%$ & $61 \%$ & $11 \%$ & $28 \%$ & 0.046 & \\
\hline
\end{tabular}

${ }^{1}$ Agree; ${ }^{2}$ Disagree; ${ }^{3}$ Uncertain; ${ }^{4} P$-values are indicators of change. A $p$-value less than 0.05 , indicates a significant change in opinions among participating stakeholders from the MIDP to the APDP

\subsection{Programme that Complies with WTO Requirements}

The MIDP could be classified as a subsidy in accordance with Article 1 of the WTO Agreement (WTO, 2008, p. 229). The access to MIDP benefits was limited by the stipulations of the relevant Chapters and Rebate Items contained in the Schedules of the Customs and Excise Act No. 91 of 1964 and can therefore also be classified as a specific subsidy (SARS, 2004, pp. 1 \& 6; WTO, 2008, p. 230). One of the policy instruments that were included in the MIDP is the IEC scheme. Under the IEC scheme credits were granted according to the value of exports in the automotive industry. Although benefits under the IEC scheme could be obtained only upon importation, the granting of the IRCCs were dependent upon the export performance of the industry. For this reason, the export performance requirement of the IEC scheme included in the MIDP could possibly be classified as a prohibited subsidy in terms of Article 3 of the WTO Agreement (Le Roux, 2007, p. 2; WTO, 2008, p. 231). This risk was confirmed by Australia's threats to lodge a complaint with the WTO when their automotive industry was seen to be affected by leather seat 
cover exports by South African firms. The strong competition as a result of the MIDP increased the risk of Australian companies losing manufacturing contracts (Flatters, 2005, pp. 13-14).

Another MIDP policy instrument that was at risk of being non-compliant with WTO requirements was the DFA. Article 3(1) of the WTO General Agreement on Tariffs and Trade of 1986 prohibits the granting of benefits to domestic production, if such benefits are not also afforded to foreign production (WTO, 1986, p. 6). The DFA was an allowance for the reduction of import duties, which was granted to OEMs that manufactured for the South African market. The allowance could be used to reduce the customs duty value of components and subsequently that of motor vehicles. The rationale behind the DFA was that manufacturers would aim to produce more vehicles locally for the domestic market in order to receive benefits to support importation of complementary vehicles to compete with other segments of the market. According to Article 3(1), imported and locally produced products should be treated equally. However, the DFA created an advantage for local manufacturers that was not available to foreign manufacturers. There was therefore a risk that the DFA could be a discriminatory subsidy.

These risks were reflected in the opinions of the participating stakeholders as the majority (72\%) was of the opinion that the MIDP did not comply with WTO requirements.

On the contrary, the majority (67\%) of the participating stakeholders were of the opinion that the APDP complies with WTO requirements. This change may be as a result of the amended policy instruments of the APDP. The APDP provides support for domestic production irrespective of where the products are sold or by whom in the form of the VAA, where the DFA was awarded to manufacturers for vehicles produced specifically for the domestic market (Deloitte and Touche, 2009, p. 2; SAABC, 2008a, p. 3; SARS, 2009, pp. 59-60). The APDP also employs a production-based policy instrument, namely the PI (Deloitte and Touche, 2009, p. 2), rather than an export-based policy instrument such as the IEC scheme (Black \& Mitchell, 2002, p. 13).

\subsection{Sustainability of Exports}

The majority (86\%) of participating stakeholders were of the opinion that the MIDP created sustainable exports. The risk of potential WTO action against the MIDP that could compromise sustainability, was evidently rated as low given the South African government's known intent to remove the cause of the risk under the APDP (the IEC scheme that was an incentive contingent upon export performance and the amendment of the provisions included in the DFA that only benefits production for the local market).

The same level of agreement was not evident regarding the anticipated impact of the APDP in this regard. Only $36 \%$ of the participating stakeholders were of the opinion that the APDP will facilitate sustainable exports. While the MIDP contributed to a major increase in exports, the sustainability of the surge in exports is questionable as it is possible that the removal of the IEC scheme could result in the collapse of or disinvestment by entities focused on the component export market, negatively impacting on its sustainability. The extensive focus on particularly catalytic converter exports was as a result of the strategy followed by many assemblers to generate high value component exports (with high value local raw material input of platinum group metals) on a large scale only to generate import rebates to reduce import tariffs in respect of the importation of motor vehicles (Black \& Bhanisi, 2007, pp. 141-142).

From the industry's perspective, catalytic converters offered a particularly attractive component. It generated a high value of incentives for relatively modest economic activity. From a taxpayer's perspective they offered a costly alternative, as high value incentives were provided for disproportionately low employment and other economic benefits (Dewar, 2012). This resulted in government introducing reduced valuation of platinum group metal content on a mid-term revision of the MIDP (SARS, 2004, p. 18). The change to an incentive based on production value-add rather than export value, appears to be a significant cause for the increased uncertainty.

Evidently, manufacturers will receive much less support for exports under the APDP than under the MIDP. Furthermore, import tariffs in most developing countries and the United States of America are higher than the stabilised tariffs under the APDP (Pitot, 2012). This may create an incentive for importation. The sustainability of exports may depend a lot on the success of the other instruments included in the APDP. Given the policy 
uncertainty, the outlook for the sustainability of exports, especially for components with high value raw material content, appears to be questionable.

\subsection{Imports, Exports and the Automotive Industry Trade Balance}

The trade balance represents the difference between the value of imports and exports. By enabling manufacturers to import at reduced tariffs, the opportunity for rationalisation is created as manufacturers can focus on specialising in the manufacture of selected models and importing the remaining models. The MIDP structure was criticised for making it much easier to obtain duty rebates than to facilitate the rationalisation of the industry (Black, 2002, p. 7; Black \& Bhanisi, 2007, p. 140; Greenwald, 1973, p. 37). More specifically, the IEC scheme functioned via both imports and exports. The South African automotive industry's resulting considerable and sustained negative trade balance (NAAMSA, 2007, p. 16; AIEC, 2009, p. 4), would not support an unqualified conclusion on the netexport subsidy effect of the MIDP in general and the IEC scheme in particular.

The value of imports (in nominal terms), including component imports, increased by 564\%, from R16.4 billion in 1995 to R108.9 billion in 2008. As a result, the automotive industry trade balance has been negative since 1995, with the exception of 1998 (AIEC, 2009, p. 4; NAAMSA, 2007, p. 16). In line with documented performance, the majority (58\%) of participating stakeholders were of the opinion that the MIDP did not succeed in decreasing imports.

Likewise, the majority (89\%) of participating stakeholders were of the opinion that the MIDP satisfied the CSF of increased exports. The AIEC (2009, p. 4) and NAAMSA (2007, p. 16) also indicated that the value of exports increased more than twenty fold (in nominal terms) from R4.2 billion in 1995, when the MIDP was first implemented, to R94.2 billion in 2008.

Despite the industry trade balance being in deficit for more than a decade (except for one year), starting at R12.2 billion in 1995 and increasing to R14.7 billion in 2008 (in nominal terms) (NAAMSA, 2007, p. 16; AIEC, 2009 , p. 4), the majority (64\%) of stakeholders were of the opinion that the MIDP created an improved industry trade balance. It is possible that participating stakeholders related this CSF to their MIDP projects' contributions to the trade balance and did not consider the overall industry dynamics. Based on aggregated industry data, the MIDP did not create an improved industry trade balance in the period reviewed up to 2008.

For the APDP there was a significant change in opinions evident in an increase in the level of uncertainty among stakeholders for all three CSFs. This can most likely be attributed to the change in criterion to qualify for the PI. The PI will be granted based on the amount of local value added whereas the MIDP criterion was the value of exports generated. Thus, there will be a transition from an export-based instrument to a production-based instrument (Deloitte and Touche, 2009, p. 2). In addition, there is concern that the stabilised level of import tariffs could be too low, which may increase imports or decrease exports or both (Pitot, 2012).

Manufacturers include import tariffs in their pricing. The MIDP created an opportunity for cheaper vehicles as a result of the gradual decline in tariffs over a number of years. No such mechanism is included under the APDP. The introduction of stable tariffs until 2020 may have a detrimental impact on the affordability of vehicles. This may well further motivate OEMs to manage manufacturing costs by sourcing components where they can be obtained at the best price. This could create opposing objectives. On the one hand the APDP aims to facilitate an increase in value add and on the other it continues to strive to create more affordable motor vehicles. If the APDP does not provide enough support to component manufacturers to manufacture technology intensive components at competitive prices, OEMs may well turn to foreign component manufacturers to remain competitive. Not only could this result in increased imports, it could also result in decreased exports as the demand for high technology components could possibly not be satisfied by local component manufacturers.

On the other hand, the VAA may enable OEMs to manufacture units to satisfy the demand for both the local and foreign markets. Whether or not local OEMs will be allowed to manufacture a specific model for foreign markets would depend on the strategies of their global parent companies (Black \& Bhanisi, 2007, p. 146; Black, 2002, p. 6; Kaggwa et al., 2007, p. 686). 


\subsection{Local Content of Motor Vehicles}

In 2008 and 2009, the average local content of vehicles assembled in South Africa was 35\% (SAAW, 2009). In measurement terms, local content levels below $40 \%$ are very low (Black \& Bhanisi, 2007, p. 144), as this may include imported materials and parts in local components.

Prior to the introduction of the MIDP, programmes included local content requirements to which manufacturers had to adhere if they were to benefit from them (Black \& Mitchell, 2002, p. 2). These requirements were removed from the MIDP. This, coupled with declining import tariffs, resulted in a decrease in local content (Black \& Bhanisi, 2007, p. 144). This is because, with less protection and no local content requirements, it became easier to use imported components to facilitate the reduction of manufacturing input costs (Black \& Bhanisi, 2007, p. 144). The 2008/2009 level of local content was still much better than the $20 \%$ local content level which prevailed during the 1960s.

Despite the documented performance of the MIDP, the majority (61\%) of participating stakeholders were of the opinion that the MIDP satisfied this CSF. It is possible that stakeholders responded to this survey question with reference to the local content levels of their own operations rather than those of the industry. The aim of this article was to obtain stakeholders' opinions regarding the performance of the South African automotive industry and not on the individual performance of participating stakeholders. As the possibility that stakeholders did not formulate responses based on the performance of the automotive industry as a whole could not be rebutted, greater weight was attributed to documented performance. Therefore, based on industry data the MIDP did not create an increase in the local content of motor vehicles.

Regarding the APDP there was a significant change in assessment evident in an increase in the level of uncertainty (from 6\% to 36\%), although the majority (58\%) of participating stakeholders were of the opinion that the APDP will contribute towards increasing the local content of motor vehicles. In part the uncertainty could be due to the delicate balance between the four policy instruments of the APDP. For example, if the VAA is too high, the need for OEMs to source components locally to gain the PI could be diminished.

Whether or not this local content will increase, will be evident only after the APDP has been in place for a period of time. However, there is a significant drive under the APDP to create an increase in overall local value added. The PI will be based upon the amount of local value added which will create an incentive to increase local content in order to gain access to the PI's benefits (Deloitte \& Touche, 2009, p. 2). The PI is to replace the IEC scheme as included in the MIDP. There is thus a transition from an export-based instrument to a production-based instrument (focusing on value added), which would appear to support increased local content.

\subsection{Increase in Local Content of Components}

The average local content of components produced locally during 2008 was between $70 \%$ and $80 \%$ (SAAW, 2009). In line with these reported statistics, the majority (64\%) of participating stakeholders agreed that the MIDP created an increase in the local content of components.

There was a significant change in the assessment of the APDP evident in the increase in the level of uncertainty among participating stakeholders (from 11\% to 33\%) regarding the ability of the APDP to achieve this CSF.

To date, the definition of what is regarded as 'value-add' under the PI has not been clarified. This instrument is intended to assist in encouraging local component production. An industry observer commented that much of the success of the PI will depend on the finalised definition (Pitot, 2012). The element of uncertainty will probably be removed once the definition has been finalised and once OEMs have started deploying their APDP aligned supply chain strategies. 


\subsection{Affordability of Motor Vehicles}

A study conducted by Barnes, Kaplinsky and Morris (2003, p. 17), revealed that there was no evidence that the MIDP resulted in increased motor vehicle prices for domestic consumers. A follow-up study by Barnes, Kaplinsky and Morris (2005), indicated that prices for motor vehicles at the lower end of the range in South Africa were higher than prices in United Kingdom countries, thereby contradicting the results of the previous study.

Kaplan (2003, p. 21) indicated that the prices of South African motor vehicles were probably higher than vehicle prices in Europe. However, Kaplan refrained from drawing a final conclusion owing to difficulties in price comparisons encountered in price studies, such as the effect of the exchange rate, the unavailability of factory prices and the differences in standard specification levels of nominally the same vehicle.

Subsequent to the above studies, the Competition Commission of South Africa (CCSA) conducted a price study initiated in terms of the Competition Act No. 89 of 1998, on account of numerous complaints lodged by South African consumers. It was concluded that the prices of South African motor vehicles were, on average, $14 \%$ higher than the prices of similar vehicles in the European Union (CCSA, 2005, p. 3).

Price comparisons using the consumer price index (CPI) and the prices of automotive products can only provide a rough estimate of whether automotive prices are indeed lower as a result of the MIDP (Flatters \& Netshitomboni, 2006, p. 7). However, it may be worth noting that automotive prices increased at well below the rate for consumer price increases from 2001 onwards (Econometrix as cited in NAAMSA, 2007, p. 7).

Only half of the participating stakeholders were of the opinion that the MIDP satisfied this CSF. The survey question on the affordability of motor vehicles was directed only at the initial purchase cost of motor vehicles and not the total cost of ownership (service, maintenance and running costs). It was difficult to determine the extent of the MIDP's contribution towards affordability of motor vehicles as no studies could be found in the public domain where the affordability of motor vehicles with and without the MIDP was compared. In addition, the above price studies located in the public domain did not deliver consistent, comparable results.

Price forming in the market is subject to complex dynamics. An important driver is competition. The import-support part of the IEC scheme resulted in an increase in the number and value of light vehicles imported from some 26000 and R0.2 billion in 1995 to some 306000 and R30.3 billion in 2006 (NAAMSA, 2009; AIEC, 2009). In this period imports increased from $7 \%$ to $45 \%$ of the market. From the increase in the number and value of imported vehicles in the presence of continually reducing import tariff levels, it can be understood that competitive forces were brought to bear on pricing of locally produced light vehicles in particular and light vehicle prices in general. Inspection of prices of vehicles show that affordable imported vehicles from low manufacturing cost countries such as India, China and to some extent Korea and Japan offered South African light vehicle buyers affordable options, albeit not from locally manufactured vehicles. It stands to reason that the competition afforded by these low cost alternatives moderated pricing of locally manufactured light motor vehicles. It therefore appears reasonable to accept the opinions of participating stakeholders as valid.

In the opinion of $44 \%$ of the participating stakeholders the APDP will satisfy this CSF. Yet there was a significant change, with an increase in the level of uncertainty (from 11\% under the MIDP to $36 \%$ for the APDP) among participating stakeholders. It may be difficult to project the anticipated implementation results in this regard, as the cost of motor vehicles is impacted by various extraneous factors such as the exchange rate and carbon and other taxes. As with the affordability of components, the stabilisation of import tariffs under the APDP may negatively impact the affordability of light motor vehicles.

\subsection{Local Research and Development Activities}

Although there was an increase in local investment under the MIDP, investment in facilities (plants, machinery and tooling) made up the bulk of total investment. Overall, investment in the support infrastructure for the period 1997 to 2009 was lightweight, being $10 \%$ or less of total expenditure. In addition, the biggest portion of investment in support infrastructure could be attributed to technical fees paid to foreign experts, and not local 
research and development (Kaggwa et al., 2007, p. 686; NAAMSA, 2007, p. 17; NAAMSA, 2009). The majority (53\%) of participating stakeholders were also of the opinion that the MIDP did not create an increase in local research and development activities.

Of the participating stakeholders, 39\% agreed and 39\% were uncertain whether the APDP will achieve this CSF. Although there is still an element of uncertainty regarding the anticipated impact of the APDP, it appears that participating stakeholders anticipate that the APDP will create an increase in local research and development activities. The aforementioned could be as a result of the fact that the AIS include provisions for increased support regarding research and development performance, while the MIDP did not provide similar support (DTI 2010a, p. 10). This is further supported by the decrease in the level of disagreement among participating stakeholders from $53 \%$ to $22 \%$.

On the other hand, the research and development initiatives may depend on the finalised definition of "value added" in the PI. This definition may indicate the level of innovation required to qualify for this incentive. An increased level may motivate increased research and development activities.

One must also keep in mind that the integration of OEMs into the operations of their global parent companies leaves them with little leverage on where research and development takes place. This decision is taken by the global parent companies and may be impacted by their strategies which may include investment in other countries with automotive incentives. While the opinions of the global parent companies are not within the scope of this paper, the current policy uncertainty does not create a favourable investment environment. Global parent companies can then be expected to favour countries with favourable incentives and where there is policy certainty (as opposed to the uncertain APDP) (Barnes \& Kaplinsky, 2000, p. 801; Barnes \& Morris, 2008, pp. 34 \& 37; Black 2001, p. 9; Kaggwa et al., 2007, p. 687).

\subsection{Diversification of Component Exports}

A policy concern regarding the increase in component exports was observed. One of the objectives of the MIDP was to increase exports. However, the IEC scheme resulted in the manufacturing of components to generate IRCCs to be used again to import. The components export basket was dominated by peripheral components. This refers to components with high value raw material content, which do not require many value-adding activities (Black, 2002, p. 12). Components requiring technological value-adding activities comprised only $8 \%$ of total component exports in 2000 (Barnes \& Kaplinsky, 2000, p. 803). This trend negatively affected the MIDP's objective of creating sustainable employment levels and increasing local research and development (DTI, 2003, pp. $10 \& 45-48)$.

For a number of years, catalytic converters dominated the components export industry as explained in section 4.2. In 2008, catalytic converters made up 55\% of component exports (AIEC, 2009, p. 21). Catalytic converters consist of platinum and stainless steel and are raw material intensive. Most of the value generated is attributable to its raw material content, rather than innovative processes that may result in increased employment opportunities. This concern was also identified as an industry development constraint by the DTI in its Industrial Policy Action Plan (DTI, 2010b, p. 55).

The majority $(56 \%)$ of the participating stakeholders were of the opinion that the MIDP created diversified component exports to some extent. The survey question was not formulated so as to guide participating stakeholders to take the economic value add of components into account. Therefore it appears that the MIDP has created diversified component exports in terms of variety but not in terms of value add.

For the APDP there was a significant change evident in an increase in the level of uncertainty among stakeholders. $36 \%$ of participating stakeholders were uncertain about whether the APDP will create diversified component exports. While the policy intent is to achieve deepening and broadening of the supply chain, the element of uncertainty will most likely only be removed once OEMs have started deploying their APDP-aligned supply chain strategies (that is, will OEMs make more extensive use of domestic component manufacturers?). 
It could be argued that the PI may better incentivise the production of low value-add components merely to generate credits for use on importation of high value-add components (as was done under the IEC scheme). On the other hand, the industry's focus could shift to increasing production in vehicles to generate credits under the VAA that can be used to import a percentage of their components duty free.

While it appears uncertain to what extent the APDP will contribute to the creation of diversified component exports, comments by participating component manufacturers indicated that a high level of skepticism remains. There is an expectation that the industry will continue to rely on importation of components which may result in the gradual disappearance of the local components industry, unless a supporting incentive is introduced to assist component manufacturers in becoming more competitive in comparison with their foreign counterparts.

\subsection{Affordability of Components}

The key customer base of component manufacturers is the OEMs. The opinions of some of the dominant OEMs could therefore be considered in order to determine whether or not they believe components have become more affordable under the MIDP (Black, 2002, p. 6; Black \& Bhanisi, 2007, p. 146; Kaggwa et al., 2007, p. 686).

Between $75 \%$ and $85 \%$ of the cost of a vehicle can be attributed to high material costs, which are the ingredients of components. During 2010, Bill Stephens, the then general manager of communications at Volkswagen South Africa (VWSA), claimed that material prices in India and China are between 20\% and $40 \%$ more competitive than those in South Africa, while in Europe material prices are between 10\% and 20\% more competitive. This competitive disadvantage was also claimed by Evan Dold, as the vice-president of global purchasing and supply chain management at General Motors South Africa (GMSA). Dold claimed that South Africa had a global competitive disadvantage of between $30 \%$ and $40 \%$ for a specific grouping of components (De Lange, 2010, p. 6).

Material is the building block of components. So where material costs are high, the price of components is correspondingly high. According to Dold, there is pressure by OEMs on component manufacturers to become more cost efficient if they are to absorb the high costs of material. The components industry is impacted adversely by high electricity costs, export costs, transport costs, income tax, fluctuations in the foreign exchange rate and sales volumes of motor vehicles (De Lange, 2010, p. 6).

David Powels, as president of the NAAMSA, commented that global automotive firms were willing to invest in the South African automotive industry, but claimed that they are discouraged by the uncompetitive nature of the local industry. This could be attributed mainly to a rise in relative costs and expensive logistic chains. Powels claimed that South Africa was $20 \%$ more expensive as an automotive manufacturing base than Western Europe, and $30 \%$ to $40 \%$ more expensive than China or India. As a result, the local OEMs were importing approximately $65 \%$ of components for the manufacture of motor vehicles. Logistical costs further increased component prices owing to South Africa's distance from export markets as well as built-in inefficiencies. This was said to be limiting the local components industry to export to nearby markets, such as Mozambique, restricting the global integration of the local components industry (Venter, 2009).

The South African Automotive Benchmarking Club (2008b, p. 3) proposes that "[i]nventory control provides a sound proxy of overall cost control. This can be attributed to the fact that where inventory is effectively managed, the costs of said inventory is bound to be reduced due to the elimination of inventory write offs and emergency supply chain measures causing payment penalties". For the period 1998 to 2007, improvements in inventory control in the range of $43 \%-55 \%$ were found. Considering these improvements, it may be that the international competition brought by the MIDP forced component suppliers to adapt more efficient practices in order to meet cost pressures imposed by OEMs.

All the above-mentioned improvements regarding inventory control impact the final cost of components and therefore the improvement can be equated to an improvement in the affordability of components. Although components manufactured in South Africa are still priced less competitively than in other developing countries, there has still been an improvement in affordability. It should be noted that the MIDP does not provide support for all component manufacturing costs, for instance material and logistic costs. It was also the opinion of the majority (56\%) of participating stakeholders that the MIDP created affordable components. 
There was a significant change in assessment from the MIDP to the APDP evident in an increase in the level of uncertainty (from $14 \%$ to $33 \%$ ) among participating stakeholders. While $42 \%$ of the participating stakeholders are of the opinion that the APDP will continue to create affordable components, it is difficult to comment on the extent of the APDP's contribution in this regard. The cost of components is impacted by various variables, such as the exchange rate, logistical costs and electricity tariffs. The instability of these variables cannot necessarily be addressed by automotive policy alone.

Keeping this in mind, one cannot ignore the stabilised import tariffs (25\% on light vehicles and $20 \%$ in components) that will be introduced under the APDP. Furthermore, vehicles imported from the European Union are subjected to import duties of only $18 \%$ as a result of a preferential agreement. The impending tariffs are also lower than those in most developing countries. Considering that these tariffs can be rebated under the APDP, the effective protection afforded to the local components industry is minimal. This may have a detrimental impact on the ability of the local components industry to compete globally if the PI benefits are not taken into consideration by OEMs when doing price comparisons (Pitot, 2012).

\subsection{Rationalisation of the Number of Vehicle Models Produced Locally}

The number of models of light motor vehicles produced locally decreased from 42 model platforms in 1995 (Anonymous, 2009, p. 2) to 17 models in 2009 (NAAMSA, 2010). In line with the documented performance, the majority $(78 \%)$ of participating stakeholders were of the opinion that the MIDP created rationalisation of the number of vehicle models produced locally.

The majority (61\%) of participating stakeholders were of the opinion that the APDP will achieve this CSF. A final conclusion on the APDP's ability to create rationalisation of the number of vehicle models produced locally, will most likely only be possible upon the deployment of APDP aligned manufacturing strategies (that is, will OEMs make more extensive use of domestic component manufacturers?).

One of the objectives of the APDP is to facilitate the production of 1.2 million vehicles per annum by 2020 (DTI, 2008). The AIS, one of the policy instruments included in the APDP, aims to support this overall objective by providing an incentive to increase production levels. Assemblers able to demonstrate that they will manufacture 50000 vehicles annually will be able to benefit by receiving a cash grant. The 50000 unit threshold under the AIS is allowed to be across different model platforms (DTI, 2010a, p. 9). Therefore, it may even be possible that some of the rationalisation achieved under the MIDP could be lost. Manufacturers may opt to increase production volumes by manufacturing additional vehicle models for the local market instead of entering into international competition with sister plants of their controlling firms for increased access to export destinations.

\section{SUMMARY}

South Africa's Industrial Policy Action Plan 2011/12 - 2013/14 (IPAP) indicates the APDP as a key action programme. The economic rationale for this focus is that "[t]he automotive industry works with long forward timelines and therefore a stable and transparent policy environment is required to enable investment decision making". It continues to state that the outcome of this focus is to create "[p]olicy certainty through publication of clear implementation guidelines, procedures and associated administrative framework, including a stronger monitoring and evaluation framework with strengthened conditionalities" (DTI, 2011, p. 130-131).

While this is a commendable outcome, the IPAP indicates that the aim was to publish the details of the APDP regulations during the first quarter of 2011/12 (DTI, 2011, p. 131). At the time of writing this article, the third quarter of 2012/13 has commenced and the final APDP regulations have yet to be published. A draft version was published for comment during June 2012 (ITAC, 2012). Contradictory to the stated outcome, there is currently limited policy certainty, which has created an environment of risk for automotive decision-makers.

It is therefore not surprising that industry stakeholders have only reacted on the AIS as this is currently the only APDP instrument where there is policy certainty. It is estimated that R1.8 billion in investment commitments from assemblers and component suppliers have been secured as a result of the AIS. The reaction consists mostly of 
investments to facilitate an increase in the production levels of light motor vehicles (Werbeloff, 2011, p. 5). Such investments therefore appear to merely address increased production levels and do not necessarily guarantee increased local research and development as well as broadening and deepening of the local components industry.

Unlike the MIDP, the APDP is a WTO compliant programme due to the replacement of the IEC scheme and the DFA by the market-neutral PI and the VAA. This is important as it brings about sustainability that is a critical enabler in the creation of certainty which would create a supportive environment for the regular high levels of investment required during model change. While the APDP is WTO compliant, it may possibly reverse the most notable success of the MIDP. In 2011, the automotive industry produced 12\% of South Africa's exports (Werbeloff, 2011, p. 12). The removal of the IEC scheme together with the uncertainty regarding the interaction between the APDP policy instruments could result in a decrease in the industry's contribution to exports.

The stabilisation of import tariffs at relatively low levels under the APDP is a matter of concern among industry stakeholders. Stabilised import tariffs may have a significant impact on the industry's ability to compete globally and also to compete locally against cheaper imported vehicles. On the other hand, it may assist in bringing about better rationalisation of the industry. Since the introduction of the MIDP, rationalisation of the industry deteriorated and it is believed that this could be as a result of the gradual decrease in import tariffs (Werbeloff, 2011, p. 13).

Policy uncertainty has made it difficult to determine the impact of the APDP on the components industry. This is concerning as it is important that the APDP is perceived to support the achievement of sustained employment levels, given the widely recognised priority of employment among South Africa's socio-economic delivery imperatives. For the duration of the MIDP, the components industry was a significant source of employment in the automotive industry, and provided employment to more than double the number of employment opportunities catered for by the OEMs (Pitot, 2012; Werbeloff, 2011, p. 17). While there is an intention to provide higher levels of support to vulnerable component industries via the APDP, this support will not be sustained and it brings into question the long-term sustainability of the local components industry (Werbeloff, 2011, p. 6). It is expected that there will be major restructuring in the components industry in an attempt by component manufacturers to redefine their target markets. Where it is not possible for component manufacturers to restructure to focus on manufacturing components with increased value add, it may be possible that these component manufacturers will have to close down. This would particularly be a concern for those component manufacturers that only focus on the manufacture of components with a high raw material content.

In the emerging markets, China is currently dominating automotive production and exports (Werbeloff, 2011, p. 7). While the South African industry has improved in a local context it is still not a sustainable global automotive producer, despite the support provided. At a time where policy certainty is imperative, the South African government has been unable to create a platform of transparent regulations. In addition, a significant contributor to employment in South Africa, the components industry, has not been afforded the lead time to design strategies to address any negative (albeit unintended) policy effects.

Based on participating stakeholders' opinions and commentary by industry observers in Werbeloff (2011), the impression is created that, although the intention was to also assist the components industry, the APDP has grown to be more focused on benefiting OEMs. From a supply chain point of view it makes sense to design policy enticing global parent companies of OEMs (and thus benefiting OEMs) as it is the global parent companies that make supply chain decisions. However, this may well be to the detriment of the South African components industry. It would be advisable not to design policy with a "one-size-fits-all" approach. The South African government might have better achieved the APDP's objectives if it had placed more emphasis on early policy certainty for component manufacturers in particular, with policy instruments designed to more directly assist the local components industry to become more competitive globally.

Whether the APDP will indeed be an improvement on the MIDP and whether the automotive industry will be able to survive without support will only become evident in time. 


\section{CONCLUSION}

The aim of this article was to analyse the opinions of stakeholders on the anticipated performance of the South African automotive industry under the APDP. It was motivated by the fact that there is currently no research available on the anticipated performance of the South African automotive industry under the APDP. It also highlighted the link between stakeholders' opinions and the documented performance of the MIDP as well as the design of the APDP's policy instruments.

Based on documented performance and the opinions of participating stakeholders, the MIDP satisfied six of the 12 CSFs (CSFs 2, 4, 6, 7, 11 and 12 in Table 2) and failed to satisfy the remaining six CSFs (CSFs 1, 3, 5, 8, 9 and 10 in Table 2). Based on the opinions of participating stakeholders, it is anticipated that the APDP will satisfy four of the 12 CSFs (CSFs 1, 5, 6 and 9 in Table 2) and there is uncertainty as to whether the APDP will be able to satisfy the remaining eight CSFs.

Policy uncertainty impacts negatively on the investment decisions of stakeholders. Where there is policy uncertainty, the perceived risk impacts the opinions of relevant stakeholders. Furthermore, amending the design of policy instruments may result in the achievement of objectives which could previously not be achieved. However, the opposite is also true. It is therefore recommended that a combination of policy instruments should not attempt to achieve too many policy objectives simultaneously. Furthermore governments should ensure that policy design is transparent and is finalised and communicated early enough to afford relevant stakeholders sufficient time to respond appropriately.

\section{AUTHOR INFORMATION}

Evádne Bronkhorst, senior lecturer in the Department of Taxation at the University of Pretoria, South Africa. Currently involved in studies regarding customs and excise duties. E-mail: evadne.bronkhorst@up.ac.za (Corresponding author)

Jasper Steyn, Professor in the Department of Engineering and Technology Management and the Graduate School of Technology Management, University of Pretoria, South Africa. Currently involved in studies on management of innovation and product development in automotive component manufacturing. E-mail: jasper.steyn@up.ac.za

Madeleine Stiglingh, Professor in and Head of Department of the Department of Taxation at the University of Pretoria, South Africa. Currently involved in studies relating to a number of tax related matters. E-mail: madeleine.stiglingh@up.ac.za

\section{REFERENCES}

1. AIEC - Automotive Industry Export Council. (2009). Automotive trade data 2009: South Africa. Pretoria: AIEC.

2. Alm, J. (1988). Uncertain tax policies, individual behavior and welfare. The American Economic Review, 78(1):237-245. Retrieved June 8, 2012, from JSTOR database.

3. Anonymous. (2009). Overview of the SA automotive industry. South African Automotive Yearbook 2009. KwaZulu-Natal: Lynn Galbraith.

4. Barnes, J. \& Kaplinsky, R. (2000). Globalization and the death of the local firm? The automobile components sector in South Africa. Regional Studies, 34(9):797-812. Retrieved April 6, 2009, from Informaworld database.

5. Barnes, J., Kaplinsky, R. \& Morris, M. (2003, September). Industrial policy in developing economies: developing dynamic comparative advantage in the South African automobile sector. Paper presented at the Trade and Industrial Policy Annual Forum, Johannesburg, 1-27. Retrieved April 8, 2009, from http://www.tips.org.za/files/727.pdf

6. Barnes, J., Kaplinksy, R. \& Morris, M. (2005). SA car prices compare favourably. Retrieved April 8, 2009, from http://qed.econ.queensu.ca/faculty/flatters/writings/BKM_car_prices_busrpt_050927.pdf 
7. Barnes, J. \& Morris, M. (2008). Staying alive in the global automotive industry: What can developing economies learn from South Africa about linking into global automotive value chains? The European Journal of Development Research, 20(1):31-55. Retrieved April 8, 2009, from Proquest database.

8. Bizer, D.S. \& Judd, K.L. (1989). Taxation and uncertainty. The American Economic Review, 79(2): 331336. Retrieved June 8, 2012, from JSTOR database.

9. Black, A. \& Bhanisi, S. (2007). The SA automotive industry in a globalizing world. What has happened to imports? Trade and Industry Monitor, 38:131-152. Retrieved April 6, 2009 from

http://www.tips.org.za/files/Trade_Industry_Monitor_Vol_38_2007.pdf

10. Black, A. (2001). Globalisation and restructuring in the South African automotive industry. Journal of International Development, 13(6):1-31. Retrieved April 6, 2009, from

http://www.commerce.uct.ac.za/Economics/Programmes/postgraduate programmes/masters/Specialisation s/TRP/Research/Black JID.pdf

11. Black, A. (2002). The export 'success' of the Motor Industry Development Programme and the implications for trade and industrial policy. Paper presented at the 2002 Annual Forum of Trade and Industrial Policy Strategies, Johannesburg, p. 1-20. Retrieved April 8, 2009, from http://www.tips.org.za/files/587.pdf

12. Black, A. \& Mitchell, S. (2002, January 1). Policy in the South African motor industry: goals, incentives, and outcomes. Paper presented at the Trade and Industrial Policy Strategies Annual Forum, Johannesburg, 1-16. Retrieved May 14, 2009, from http://www.tips.org.za/files/561.pdf

13. Bronkhorst, E. (2010). The review of the Motor Industry Development Programme. MCom dissertation. University of Pretoria. Retrieved July 30, 2012, from http://upetd.up.ac.za/thesis/available/etd-07262011$123026 /$

14. CCSA - Competition Commission of South Africa. (2005). MIDP review 2005: participation by the Competition Commission of SA. Retrieved April 8, 2010, from http://qed.econ.queensu.ca/faculty/flatters/writings/compcom_MIDP\%20Review_15Nov05.doc

15. Deloitte and Touche. (2009). What does the new Automotive Production and Development Programme mean for the industry? Retrieved March 13, 2010, from http://www.automotiveonline.co.za/site/files/6860/APDP Deloitte.pdf

16. De Lange, R. (2010, February 14). Onderdele verduur meeste slae in die bedryf. Sake24, p. 6.

17. Dewar, K. (2012). The catalytic converter industry in South Africa. Retrieved December 1, 2012, from http://www.saimm.co.za/Conferences/Pt2012/893-904_Dewar.pdf

18. Diamantopoulos, A. \& Schlegelmilch, B.B. (2000). Taking the fear out of data analysis. Singapore: Thomson Learning.

19. Dolan, P., Hallsworth, M., Halpern, D., King, D., Vlaev, I. (2010). Mindspace: Influencing behavior through public policy. Retrieved October 31, 2012, from http://www.instituteforgovernment.org.uk/sites/default/files/publications/MINDSPACE.pdf

20. DTI - South Africa. Department of Trade and Industry. (2003). Current developments in the automotive industry. Retrieved February 8, 2010, from http://www.dti.gov.za/publications/automotiveindustry.pdf

21. DTI - South Africa. Department of Trade and Industry. (2008, September 4). The Automotive Development Plan announcement. Retrieved March 13, 2010, from http://www.dti.gov.za/article/articleview.asp?current=1\&arttypeid=1\&artid=1629

22. DTI - South Africa. Department of Trade and Industry. (2010a). Automotive Investment Scheme programme guidelines. Retrieved July 8, 2010, from http://www.dti.gov.za/ais/ais guidelines.pdf

23. DTI - South Africa. Department of Trade and Industry. (2010b). 2010/11 - 2012/13 Industrial Policy Action Plan. Retrieved March 8, 2010, from http://www.dti.gov.za/ipap/IPAP20102013 18_FEB 2010.pdf

24. DTI - The Department of Trade and Industry. (2011). Industrial Policy Action Plan2011/12 - 2013/14. Retrieved July 29, 2012, from http://www.info.gov.za/view/DownloadFileAction?id=144975

25. Edmiston, K., Mudd, S., \& Valev, N. (2003). Tax structures and FDI: The deterrent effects of complexity and uncertainty. Fiscal Studies, 24(3): 341-359. Retrieved June 8, 2010, from http://onlinelibrary.wiley.com/doi/10.1111/j.1475-5890.2003.tb00087.x/pdf 
26. Flatters, F. (2005, November 5). The economics of MIDP and the South African motor industry. Paper presented at the TIPS / NEDLAC South Africa Trade and Poverty Programme (SATTP) Policy Dialogue Workshop, Johannesburg. Retrieved April 8, 2009, from http://qed.econ.queensu.ca/faculty/flatters/writings/ff_economics_of_midp.pdf

27. Flatters, F. \& Netshitomboni, N. (2006). Trade and poverty in South Africa: Motor industry case study. Paper prepared for the University of Cape Town's Southern Africa Labour and Development Research Unit (SALDRU) Trade and Poverty Project. Retrieved April 8, 2009, from http://qed.econ.queensu.ca/faculty/flatters/writings/ff_nn_t\&p_motor_industry.pdf

28. GCIS - Government Communication and Information System. (2008, September 4). Transcript of postCabinet briefing. Retrieved October 25, 2012, from www.info.gov.za/speeches/2008/08090915451002.htm

29. Greenwald, D. (1973). The McGraw-Hill dictionary of modern economics. A handbook of terms and organizations. $2^{\text {nd }}$ ed. United States of America: McGraw-Hill.

30. Hall, R. E. \& Jorgenson, D. W. (1967). Tax policy and investment behavior. The American Economic Review. 57(3):391-414. Retrieved October 25, 2012 from JSTOR database.

31. ITAC - International Trade Administration Commission of South Africa. 2012. Draft Regulations for the administration of the Automotive Production Development Programme (APDP). Government Gazette 483(35464): 1-13. Retrieved July 30, 2012 from http://www.info.gov.za/view/DownloadFileAction?id=144975

32. Johnson Matthey. 2012. Export success for South Africa's automotive industry. Retrieved December 1, 2012, from http://ect.jmcatalysts.com/pdfs/2,2\%South\%20Africa.pdf

33. Kaggwa, M., Pouris, A. \& Steyn, J.L. (2007).South Africa government's support of the automotive industry: Prospects of the productive asset allowance. Development Southern Africa, 24(5):681-691. Retrieved June 7, 2009, from Informaworld database.

34. Kaplan, D. (2003, September 8-10). Manufacturing performance and policy in South Africa - a review. Paper presented at the TIPS/DPRU Forum, Johannesburg. Retrieved April 8, 2009, from http://www.tips.org.za/files/A_Review_of_South_Africas_Post-1994_Industrial_Performance.pdf

35. Lamprecht, N. (2006). Analysis of the Motor Industry Development Programme (MIDP) as a promotional tool for the South African automotive industry in the global automotive environment. MCom dissertation. University of South Africa. Retrieved June 30, 2009, from http://uir.unisa.ac.za/bitstream/10500/2378/1/dissertation.pdf

36. Lamprecht, N. (2009). The impact of the Motor Industry Development Programme (MIDP) on the export strategies of the South African light motor vehicle manufacturers (1995-2008). DCom thesis. University of South Africa. Retrieved July 15, 2010, from http://uir.unisa.ac.za/bitstream/10500/3262/1/thesis_lamprecht_n.pdf

37. Le Roux, M. (2007, August 2). Surprise MIDP break for vehicle manufacturers. Business Day. Retrieved April 3, 2009, from http://qed.econ.queensu.ca/faculty/flatters/writings/midp_surprise_break_bd_071001.pdf

38. NAAMSA - National Association of Automobile Manufacturers of South Africa. (2007). NAAMSA annual report. Retrieved June 26, 2009, from

http://www.naamsa.co.za/ar2007/2007\%20NAAMSA\%20Annual\%20Report.pdf

39. NAAMSA - National Association of Automobile Manufacturers of South Africa. (2009). Quarterly review of business conditions: Motor vehicle manufacturing industry: $4^{\text {th }}$ quarter, 2009. Retrieved March 4, 2010, from http://www.naamsa.co.za/papers/2009_4thquarter/

40. NAAMSA - National Association of Automobile Manufacturers of South Africa. (2010). Car/LCV MIDP: Monitoring of key benchmarks: 2001 - 2009. Retrieved March 4, 2010, from http://www.naamsa.co.za/papers/20100201/CAR-LCV\%20MIDP\%20\%20MONITORING\%20OF\%20KEY\%20BENCHMARKS\%20-\%202001\%20-\%202009.doc

41. NAAMSA - National Association of Automobile Manufacturers of South Africa. (2012). Quarterly review of business conditions: Motor vehicle manufacturing industry: $1^{\text {st }}$ quarter, 2012. Retrieved July 13, 2012 from http://www.naamsa.co.za/papers/2012_1stquarter/index.html

42. OECD - Organisation for Economic Co-operation and Development. (2001, November 26-27). New horizons and policy challenges for foreign direct investment in the 21st century. Foreign direct investment in South Africa. Paper presented at the OECD Global Forum on International Investment, p. 1-9. Retrieved April 6, 2009, from http://www.oecd.org/dataoecd/24/38/2422913.pdf 
43. OICA - Organisation Internationale des Constructeurs d'Automobiles. (2007). Economic contributions. Retrieved July 13, 2012, from http://oica.net/category/economic-contributions/

44. Pitot, R. (2012). The APDP - Summary \& guidelines. Retrieved July 10, 2012, from http://naacamdirectory.webhouse.co.za/pages/32908

45. Policy Studies Institute. (2006). Designing policy to influence consumers: Consumer behaviour relating to the purchasing of environmentally preferable goods. Retrieved October 31, 2012, from http://ec.europa.eu/environment/enveco/pdf/RealWorldConsumerBehaviour.pdf.

46. PQSTAT - Precision and Quickness of Statistical Analyses. (2012). The McNemar test, the Bowker test of internal symmetry. Retrieved October 31, 2012, from http://pqstat.com/?mod_f=bowker_mcnemar

47. Rodrik, D. (1991). Policy uncertainty and private investments in developing countries. Journal of Development Economics, 36: 2290242. Retrieved June 8, 2012, from http://www.gdsnet.org/GDS/Rodrik1991PolicyUncertaintyInvestmentJDE36.pdf

48. SAABC - South African Automotive Benchmarking Club. (2008a). How does the APDP stack up against the MIDP? South African Automotive Benchmarking Club Newsletter, 11(5):1-7. Retrieved May 13, 2010, from http://www.automotiveonline.co.za/site/files/6860/11e SAABC\%20September\%202008(1).pdf

49. SAABC - South African Automotive Benchmarking Club. (2008b). The times they are achangin' - but has the South African auto component industry? South African Automotive Benchmarking Club Newsletter, 11(1):1-9. Retrieved March 13, 2010, from http://www.bmanalysts.com/site/Upload/1\%20SAABC\%20Newsletter\%20January-February\%202008.pdf

50. SAAW - South African Automotive Week. (2009, July 22). Focus on partnerships. Retrieved December 3 , 2009, from http://www.saaw.co.za/News/09-07-22/focus_on_partnerships.aspx

51. SARS - South Africa. South African Revenue Service. (2004). Quick reference guide to the Motor Industry Development Programme (MIDP). Retrieved May 12, 2009, from http://www.sars.co.za/uploads/images/0_sc-id-06_-_quick_reference_guide_to_the_midp_-_rev[1][1]._1_01.03.2004.pdf

52. SARS - South Africa. South African Revenue Service. (2009). Customs and Excise Act No. 91 of 1964 : Schedule 3. Retrieved May 13, 2009, from http://www.sars.co.za/Tools/Documents/DocumentDownload.asp?FileID=60424

53. SAS Institute. (2010). Base SAS (R) 9.2 procedures guide: statistical procedures. $3^{\text {rd }}$ ed. Retrieved April 6 , 2010, from http://support.sas.com/documentation/cdl/en/procstat/63104/PDF/default/procstat.pdf

54. Smulders, S. \& Stiglingh, M. (2008). Annual tax compliance costs for small businesses: a survey of tax practitioners in South Africa. South African Journal of Economic and Management Sciences, 11(3):354371. Retrieved April 18, 2010, from http://repository.up.ac.za/upspace/bitstream/2263/14469/3/Smulders_Annual\%282008\%29.pdf

55. South Africa: sting in the plan. (2008, September 10). Business Day. Retrieved April 6, 2009, from: http://allafrica.com/stories/200809100079.html

56. Stiglingh, M. (2008). Developing a model to evaluate the quality of the services rendered by the South African Revenue Service, DCom thesis, University of Pretoria, Pretoria. Retrieved August 10, 2010, from http://upetd.up.ac.za/thesis/available/etd-05042009-003506/

57. Venter, I. (2009, October 30). Auto bosses wring their hands over SA's declining competitiveness. Can the situation be salvaged? Engineering News, Retrieved April 30, 2010, from http://www.engineeringnews.co.za/article/end-of-the-line-2009-10-30

58. Werbeloff, A. (2011, October). Adapting for success in a changing market. Car Conference 2011. Retrieved July 29, 2012, from http://www.naamsa.co.za/papers/20120126/index.html

59. WTO - World Trade Organization. (1986). The text of the general agreement on tariffs and trade. Retrieved March 5, 2010, from http://www.wto.org/english/docs_e/legal_e/gatt47_e.pdf

60. WTO - World Trade Organization. (2008). Agreement on subsidies and countervailing measures. Retrieved April 11, 2009, from http://www.wto.org/english/docs_e/legal_e/24-scm.pdf 


\section{NOTES}

